\title{
Modulation of Epigenetic Profiles in Traffic Workers Exposed to Car Fumes in Egypt
}

\author{
Shaat R ${ }^{1}$, Abdel-Ghany SE1, Nasr $\mathbf{G M}^{2}$, Sabit $\mathrm{H}^{3 *}$ and El-Zawahry $\mathbf{M}^{1,4}$ \\ ${ }^{1}$ College of Biotechnology, Misr University for Science \& Technology, Giza, Egypt \\ ${ }^{2}$ Department of Molecular Diagnostics, Genetic Engineering and Biotechnology Research Institute (GEBRI), Sadat City University, Egypt \\ ${ }^{3}$ Department of Genetics, Institute for Research and Medical Consultations, Imam Abdulrahman Bin Faisal University, Saudi Arabia \\ ${ }^{4}$ Research and Development Center, Misr University for Science \& Technology, Giza, Egypt
}

\begin{abstract}
Air pollution is one of the most crucial public health concerns over the globe. Car fumes are major component of the pollution burden, and thought to modulate the methylation landscape of the exposed people. In the present investigation, 199 blood samples were collected from male traffic workers belonging to the Traffic Department, Ministry of Interior in Egypt. Global DNA methylation was quantified using real time PCR, and the obtained results indicated a hypermethylation in the outdoor group compared to the indoor group. Transforming growth factor (TGF- $\beta$ ) gene expression was assessed using real time PCR as an indicator for the transformation of cells from the normal to the malignant state. Data indicated that the outdoor group had an elevated level of TGF- $\beta$ expression as normalized by $\beta$ actin compared to the indoor group. Blood glucose was also reported an increased level in the outdoor compared to the indoor group. These data could be considered as a preliminary study to a larger one to underlie the risk of exposure to car fumes on traffic workers, especially the outdoor workers.
\end{abstract}

Keywords: Air pollution; Epigenetics; Methylation; TGF- $\beta$; Car Fumes; Egypt

\section{Introduction}

Environmental air pollution is one of the most serious public health problems throughout the world [1]. About 7 million people die prematurely every year as a result of air pollution [2]. A vast array of studies have indicated a strong link between exposure to air pollution and human morbidity and mortality [3]. Ambient air pollution caused $6 \%$ of total mortality, or more than 40,000 attributable cases, per year worldwide [4]. Increased number of cars raises a new challenge; Trafficrelated Air Pollution (TRAP), which has been considered as the most important source of air pollution in urban areas [5]. TRAP is a complex mixture of gases (including $\mathrm{NO}_{2}, \mathrm{SO}_{2}, \mathrm{O}_{3}$ ) and Particulate Matters (PMs) with different aerodynamic equivalent diameters, which could access the respiratory system easily via inhalation, and affect human health directly and indirectly [6]. Exhaust fumes are extremely dangerous and can seriously injure and even kill people who are exposed [7].

Recent epidemiological studies have shown that ambient air pollution exposure is associated with increased mortality and higher incidence of several diseases such as asthma, chronic obstructive pulmonary disease, neurologic disease, and cancer $[8,9]$.

The ever-changing environment has great effects on human health both at genetic and epigenetic levels [10,11]. The epigenome represents the interface between the environment and the genome [12] , and it is frequently changed in response to the environmental conditions such as diet, exercise, disease and even aging $[13,14]$. Changes in epigenome might be of transient nature, where it has minor effects on the individual phenotype [15]. When it is inheritable, epigenetic changes might lead to increased disease susceptibility and progression $[16,17]$. Therefore, understanding the epigenetic changes induced by exposure to PM may provide an important tool for dissecting the association between PM exposure and cancer because of their carcinogenicity, cytotoxicity, embryotoxicity, genotoxicity, and reproductive toxicity [18-20].

Several studies have linked changes in DNA methylation with traffic-related air pollution, although the underlying mechanisms have not been explored [21-23].

Transforming Growth Factor beta $(T G F-\beta)$ is a member of the transforming growth factor superfamily of cytokines [24]. It performs many cellular functions, including the control of cell growth, proliferation, differentiation, and apoptosis $[25,26]$. Furthermore, they do not always induce cellular transformation, and are not the only growth factors that induce cellular transformation [27]. Exposure to particle matter (as a main component in polluted air) increases the expression of TGF- $\beta$ along with other genes such as fibronectin [28]. In addition, $\mathrm{CeO}_{2}$ exposure resulted in increased level of expression of TGF- $\beta$ [29].

Here in the present study, the changes in methylation profile of $T G F-\beta$ gene has been profiled in cohort population of traffic workers in Egypt.

\section{Materials and Methods}

\section{Sample collection}

About 199 peripheral blood samples were collected from traffic workers belonging to the Ministry of Interior, Egypt upon written approval obtained from the Minister of Interior. Clear, comprehensive informed consent was obtained from every participant. Participants were classified according to the duration they spent out door or in door. Samples were collected in heparin-coated tubes and stored at $-80^{\circ} \mathrm{C}$ until being used. Blood pressure was recorded for every participant. Samples were collected from different locations in Greater Cairo as shown in Figure 1, where traffic stations were located.

*Corresponding author: Sabit H, Department of Genetics, Institute for Research and Medical Consultations, Imam Abdulrahman Bin Faisal University, Saudi Arabia Tel: +966546177974; E-mail: hhsabit@iau.edu.sa

Received November 21, 2018; Accepted December 04, 2018; Published December 13, 2018

Citation: Shaat R, Abdel-Ghany SE, Nasr GM, Sabit H, El-Zawahry M (2019) Modulation of Epigenetic Profiles in Traffic Workers Exposed to Car Fumes in Egypt. Mol Biol 8: 225. doi: 10.4172/2168-9547.1000225

Copyright: (c) 2019 Shaat $\mathrm{R}$, et al. This is an open-access article distributed under the terms of the Creative Commons Attribution License, which permits unrestricted use, distribution, and reproduction in any medium, provided the original author and source are credited. 


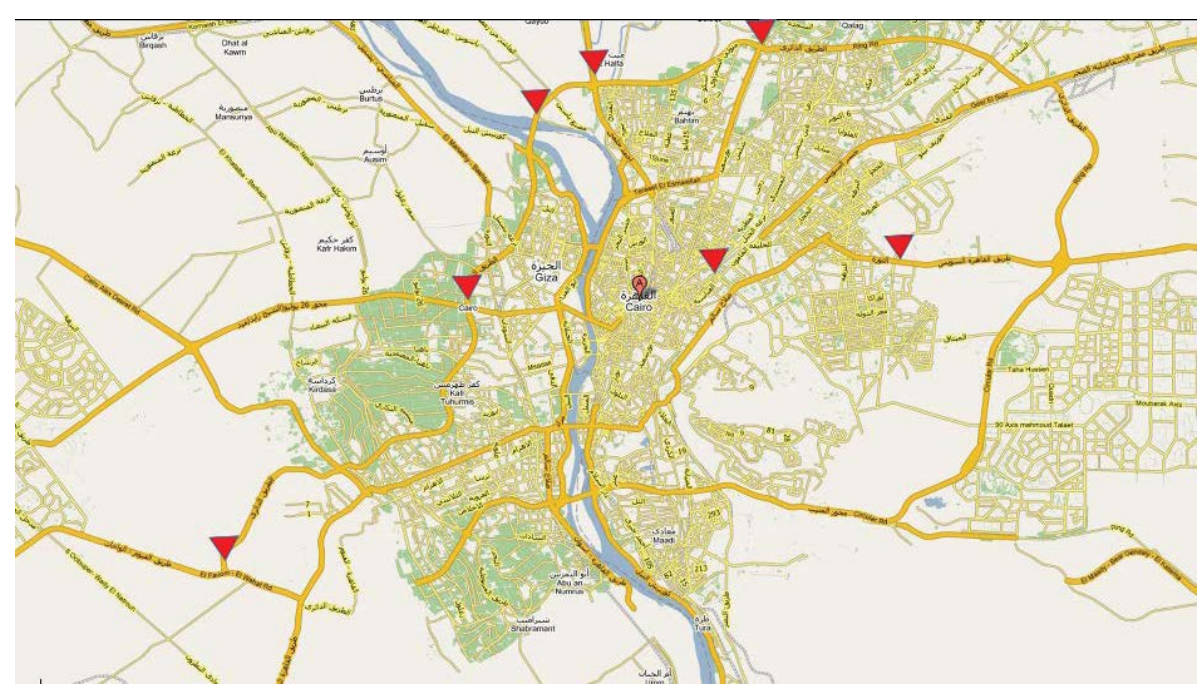

Figure 1: Greater Cairo map with the locations from which samples were collected

\section{RNA extraction}

Total RNA was extracted using RNeasy Mini Kit (Qiagen, Germany)

\section{cDNA synthesis}

The extracted RNA was converted into cDNA using First Strand cDNA Synthesis Kit (Qiagen, Germany).

\section{DNA extraction}

Genomic DNA was extracted from all samples using QIAamp DNA Mini Kit (Qiagen, Germany). The procedures were performed according to the manufacturer protocol.

\section{Target gene}

Tumor growth factor was chosen for its function as preliminary warning system for the transformation of normal cells to malignant state. The primer sequences used in the present study are presented in Table 1.

\section{Real time amplification}

Normalize the primer concentrations and mix gene-specific forward and reverse primer pair. Each primer (forward or reverse) concentration in the mixture is $5 \mathrm{pmol} / \mu \mathrm{L}$. The experiments were performed according to the following PCR program on ABI Step One Plus: $50^{\circ} \mathrm{C}$ for $2 \mathrm{~min}, 1$ cycle as a pre-PCR step, followed by $95^{\circ} \mathrm{C}$ for $10 \mathrm{~min}, 1$ cycle at $95^{\circ} \mathrm{C}$ for $15 \mathrm{~s}, 60^{\circ} \mathrm{C}$ for $30 \mathrm{~s}, 72^{\circ} \mathrm{C}$ for $30 \mathrm{~s}, 40$ cycles, and $72^{\circ} \mathrm{C} 10 \mathrm{~min}, 1$ cycle as a final extension step. All samples were performed in triplicates. Beta actin gene was used as internal control for normalization. Normalization was performed using the equation: $2^{-\Delta \Delta C T}$.

\section{Diabetes measurements}

In all blood samples obtained, the concentrations of glucoses were measured using OneTouch Verio Flex meter (USA) according to the manufacturer protocol.

\section{Global methylation quantification}

Real time PCR-based global 5-mC was performed using MethylQuant (Epigentek, USA). We followed the kit's instructions. All samples were performed in triplicates as recommended by the manufacturer.

\section{Results and discussion}

\section{Sample categorization}

Samples were categorized based on the duration spent out door or in door. A total of 199 samples were collected from outdoor and indoor male traffic worker participants as shown in Table 2. Average age was $34.9 \pm 9.14$ years as shown in Table 3 , and average duration was $10.2 \pm 6.6$ years as shown in Table 4 . Participants with history of any malignancies were excluded from the study. In addition, participants with any chronic illnesses that require long-term medications were also excluded. Blood glucose level were recorded for each participant as shown in Figure 2.

\begin{tabular}{|l|c|c|}
\hline & Forward (5-3) & Reverse (5-3) \\
\hline TGF- $\boldsymbol{\beta}$ & CATCCATGACATGAACCGACCCTT & ACGAAGTTGGCATGGTAGCCCTT \\
\hline B-actin & AGAGCTACGAGCTGCCTGAC & AGCACTGTGTTGGCGTACAG \\
\hline
\end{tabular}

Table 1: The primer sequences used in the present study.

\begin{tabular}{|l|c|c|c|}
\hline In or outdoor & Frequency & Percent & Mean \\
\hline Indoor & 63 & $31.70 \%$ & $58.80 \%$ \\
\hline Outdoor & 117 & $9.50 \%$ & 1.78 \\
\hline Indoor and outdoor & 19 & $100.00 \%$ & 0.604 \\
\hline Total & 199 & \\
\hline
\end{tabular}

Table 2: Studied population characteristics according to their field of work $(N=199)$. 


\begin{tabular}{|l|c|c|c|}
\hline \multicolumn{1}{|c|}{ Age } & Frequency & Percent & Mean \\
\hline from 20 to 30 years old & 55 & $27.60 \%$ & $16.10 \%$ \\
\hline from 31 to 35 years old & 32 & $28.10 \%$ & \\
\hline from 36 to 40 years old & 56 & $19.10 \%$ & \multirow{2}{*}{34.93} \\
\hline from 41 to 45 years old & 38 & $9.00 \%$ & \\
\hline more than 45 years & 18 & $100.00 \%$ & \\
\hline Total & 199 & & \\
\hline
\end{tabular}

Table 3: Age Characteristics of the studies population $(\mathrm{N}=199)$.

\begin{tabular}{|l|c|c|c|}
\hline \multicolumn{1}{|c|}{ Duration of exposure } & Frequency & Percent & Mean \\
\hline Less than 5 years & 62 & $31.20 \%$ & $11.10 \%$ \\
\hline from 5 to 10 years & 22 & $35.70 \%$ & $16.60 \%$ \\
\hline from 11 to 15 years & 71 & $94.50 \%$ & \multirow{2}{*}{6.604} \\
\hline more than 15 years & 33 & $5.50 \%$ & \\
\hline Total & 188 & $100.00 \%$ & \\
\hline Missing & 11 & & \\
\hline Total & 199 & & \\
\hline
\end{tabular}

Table 4: Duration of exposure to car fumes outdoor $(\mathrm{N}=188)$.

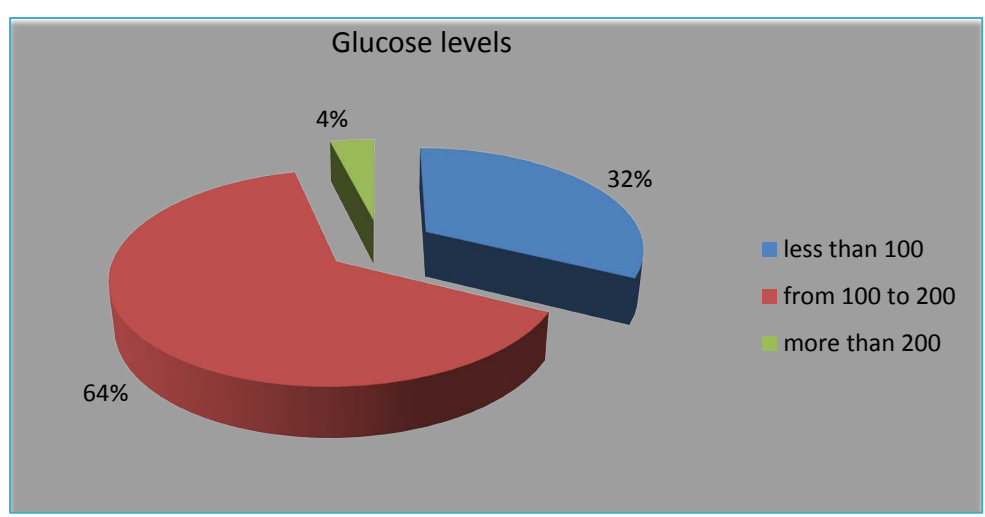

Figure 2: Blood glucose levels for participants $(\mathrm{mg} / \mathrm{dL})$

\section{Diabetes as an indicator}

Air pollution, the most pervasive environmental concern, is estimated to cause around 800,000 deaths every year worldwide [30,31]. Our results indicated that the outdoor group have suffered from higher levels of blood glucose compared to indoor group as shown in Figures 2 and 3. Cases with blood glucose level higher than $200 \mathrm{mg} / \mathrm{dL}$ were detected in the outdoor group but not in the indoor group. It has been indicted earlier that air pollution could be responsible for 3.2 million new cases of type 2 diabetes every year globally [30,32,33]. Several studies have indicated that a $10 \mu \mathrm{g} / \mathrm{m}^{3}$ increase in PM2.5 was associated with increased risk of diabetes $[22,23,34]$.

\section{Gene expression analysis}

Transforming growth factor beta $(T G F-\beta)$ gene is a multifunctional cytokine that plays crucial roles from modulation of immune-surveillance to angiogenesis [35-37]. Several literature indicated the correlation between tumor suppressor gene expression and car fumes [35,38]. Data obtained indicated that TGF- $\beta$ gene was upregulated in outdoor group compared to indoor group as shown in Figure 4 . This might be attributed to the chronic exposure to car fumes as indicated elsewhere [35,39]. Some cases reported an increase in the fold change as normalized against beta actin in indoor group, and this might refer to an early transformation of their cells from the normal to malignant state, taken in consideration that this indoor group had served outdoor for some time during the past 10 years. TGF- $\beta$ elevated expression was detected in several types of cancers.

\section{Methylation quantification}

Global methylation was quantified in the genomes of selected participants (23 participants) as shown in Figures $5 \mathrm{a}-5 \mathrm{~d}$ using real time PCR. Participants were originally categorized into outdoor group, who spent more than 10 years of working in the field (outdoor) and indoor group, who spent more than 10 years working indoor. Results obtained indicated that indoor group has lower concentration of global 5 -methylCytosine $(5-\mathrm{mC})$. However, a lower concentration of 5-mC was also obtained in outdoor cases, which might indicated an individual variation rather that being a trend in this cohort group $[1,36,40]$. The lower concentrations of $5-\mathrm{mC}$ in indoor group could be attributed to the lower levels of car fumes they exposed to, and this might resemble, in turn, the normal level of genome methylation in the total population $[20,41,42]$. The relatively elevated level of $5-\mathrm{mC}$ in the genomes of outdoor group might be due to the prolonged periods of exposure to car exhaust, as several researches indicated that chronic exposure to car fumes results in changes in the methylation landscape either globally or on loci-specific fashion $[5,41]$. 


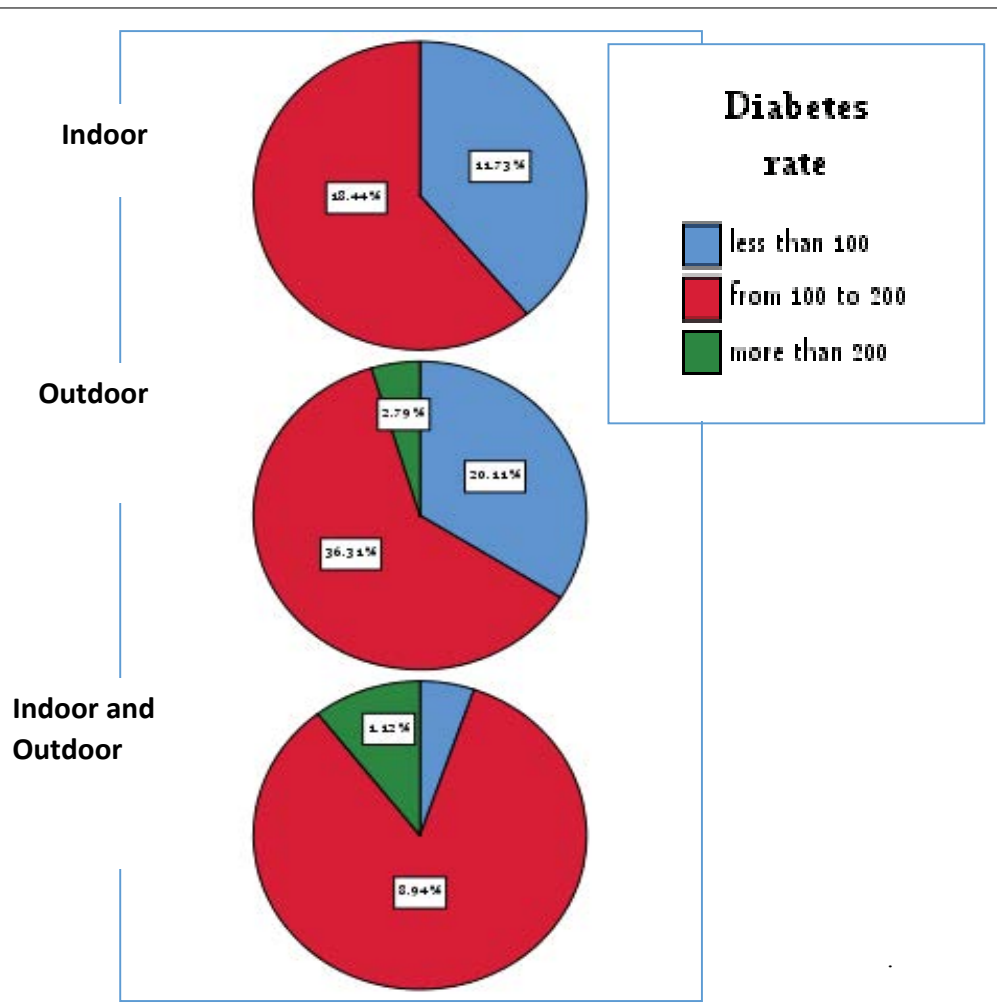

Figure 3: Prevalence of blood glucose levels in the Outdoor and Indoor groups

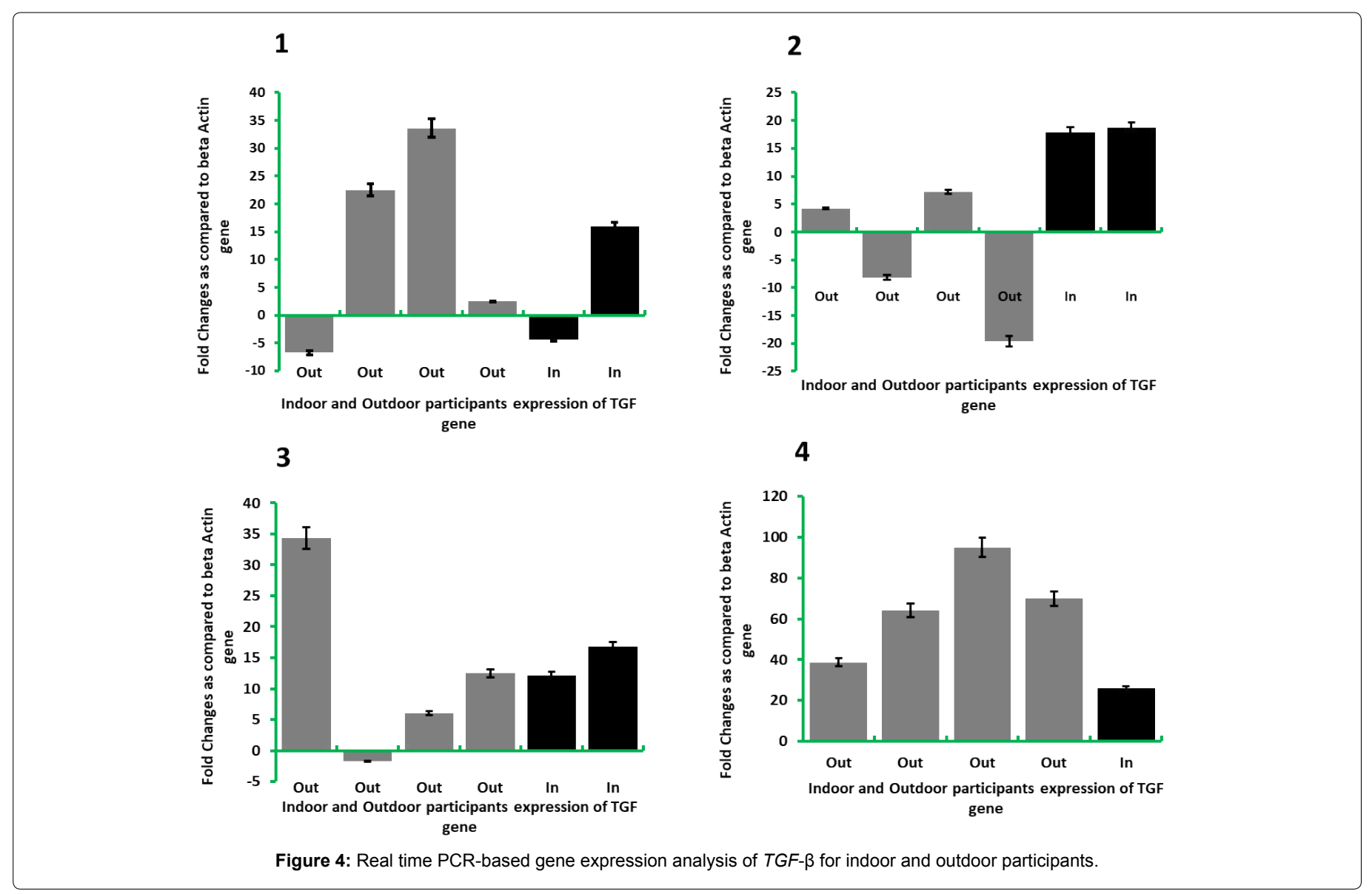




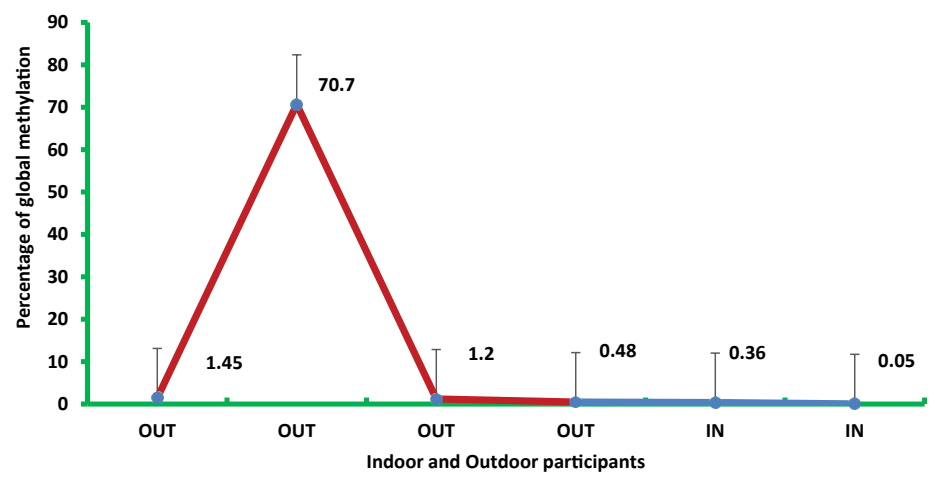

Figure 5a: Real time PCR-based global DNA methylation quantification in indoor and outdoor participants (OUT: Outdoor participants, and IN: Indoor participants).

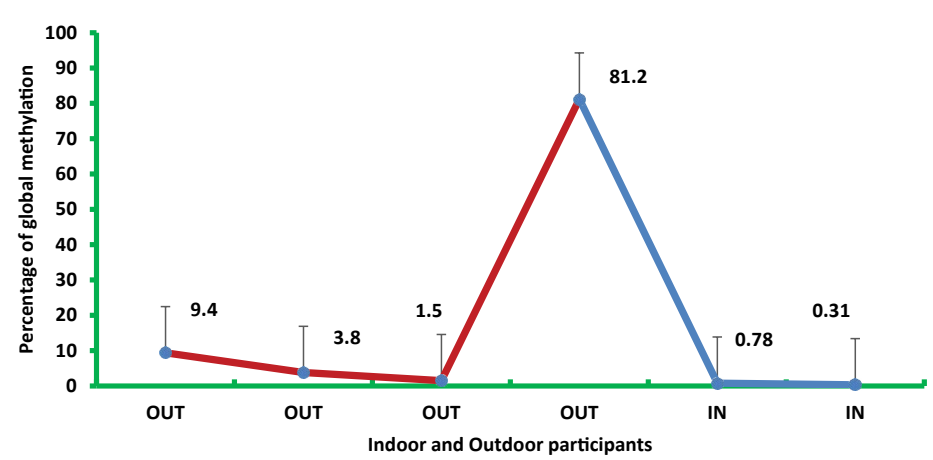

Figure 5b: Real time PCR-based global DNA methylation quantification in indoor and outdoor participants (OUT: Outdoor participants, and IN: Indoor participants).

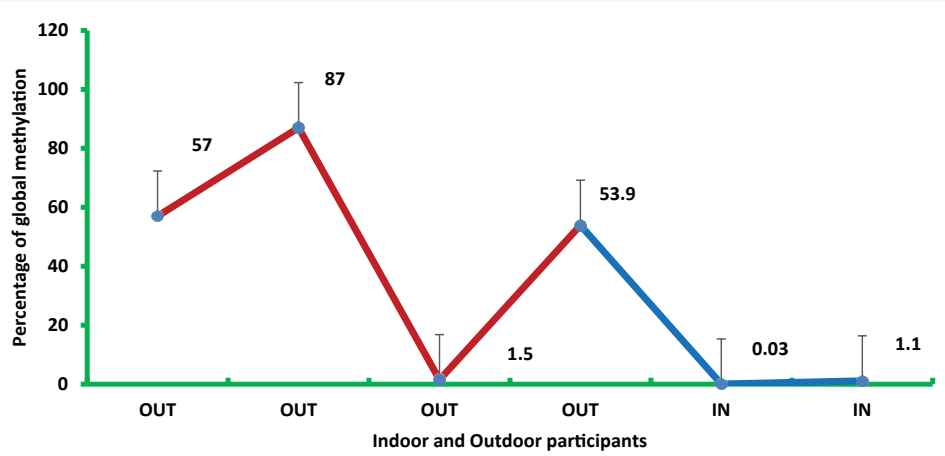

Figure 5c: Real time PCR-based global DNA methylation quantification in indoor and outdoor participants (OUT: Outdoor participants, and IN: Indoor participants).

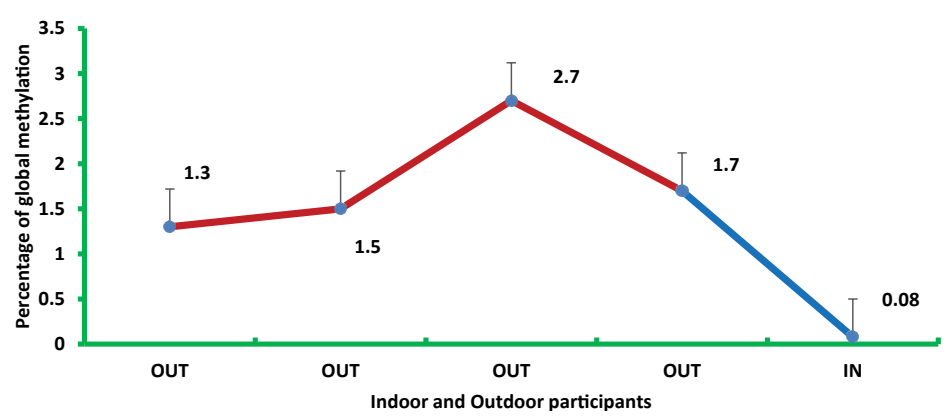

Figure 5d: Real time PCR-based global DNA methylation quantification in indoor and outdoor participants (OUT: Outdoor participants, and IN: Indoor participants). 


\section{Conclusion}

In the present study, blood samples were collected from male traffic workers in Egypt with clear informed consent being obtained. Blood glucose level were recorded for each participant. RNA was extracted and converted to CDNA and subjected real time PCR to assess the level of TGF- $\beta$ gene expression as normalized with beta actin. Results indicated that TGF- $\beta$ was up regulated generally in the outdoor group compared to the indoor group. Meanwhile, global DNA methylation was quantified using real time PCR-based technique. Data obtained showed elevated level of 5-mC in the outdoor group compared to the indoor group. These data could be consisted as preliminary to conduct a more intensive, large-scaled study to highlight the risks of developing tumors in traffic workers in Egypt, especially who spend more than 10 years working outdoors.

\section{Conflict of interest}

The authors declare no conflict of interests.

\section{Acknowledgments}

The authors thank the Minister of Interior and the Officers of Traffic departmen in the Ministry of Interior for cooperation with providing samples.

\section{References}

1. Cui JY, Li CY (2018) Epigenetics in toxicology. in: McQueen C (ed.) Comprehensive Toxicology (Third Edition). Oxford: Elsevier.

2. Delpont B, Mariet AS, Blanc C, Bejot Y, Riroud M, et al. (2018) Environmental Air Pollution: An Emerging Risk Factor for Stroke. In: Vasan RS and Sawye DB (eds.) Encyclopedia of Cardiovascular Research and Medicine. Oxford: Elsevier.

3. Jeffries MA (2018) Epigenetic editing: How cutting-edge targeted epigenetic modification might provide novel avenues for autoimmune disease therapy. Clin Immunol S1521-6616: 30015-30041.

4. Finch CE (2018) The Three Smokes in Global Mortality. In: Finch CE (ed.) The Role of Global Air Pollution in Aging and Disease. Academic Press.

5. Ding R, Jin Y, Liu X, Zhu Z, Zhang Y, et al. (2016) Characteristics of DNA methylation changes induced by traffic-related air pollution. Mutation Research/ Genetic Toxicology and Environmental Mutagenesis 796: 46-53.

6. Krauskopf J, Caiment F, van Veldhoven K, Chadeau-Hyam M, Sinharay R, et al. (2018) The human circulating miRNome reflects multiple organ disease risks in association with short-term exposure to traffic-related air pollution. Environ Int 113: 26-34.

7. lei X, Muscat JE, Zhang B, Sha X, Xiu G (2018) Differentially DNA methylation changes induced in vitro by traffic-derived nanoparticulate matter. Toxicol 395 $54-62$.

8. Shahadin MS, Ab Mutalib NS, Latif MT, Greene CM, Hassan T (2018) Challenges and future direction of molecular research in air pollution-related lung cancers. Lung Cancer 118: 69-75.

9. Leclercq B, Platel A, Antherieu S, Alleman LY, Hardy EM, et al. (2017) Genetic and epigenetic alterations in normal and sensitive COPD-diseased human bronchial epithelial cells repeatedly exposed to air pollution-derived PM2.5. Environ Pollut 230: 163-177.

10. Provenzi L, Guida E, Montirosso R (2018) Preterm behavioral epigenetics: A systematic review. Neurosci Biobehav Rev 84: 262-271.

11. Garcia-Gomez A, Rodríguez-Ubreva J, Ballestar E (2018) Epigenetic interplay between immune, stromal and cancer cells in the tumor microenvironment. Clin Immunol S1521-6616: 30031-30019.

12. Moses C1, Garcia-Bloj B, Harvey AR, Blancafort P (2018) Hallmarks of cancer: The CRISPR generation. Eur J Cancer 93: 10-18.

13. Khan MI, Rath S, Adhami VM, Mukhtar H (2018) Targeting epigenome with dietary nutrients in cancer: Current advances and future challenges. Pharmacol Res 129: 375-387.

14. Aslani S, Sobhani S, Gharibdoost F, Jamshidi A, Mahmoudi M (2018) Epigenetics and pathogenesis of systemic sclerosis; the ins and outs. Hum Immunol 79: 178-187.
15. Supic G, Zeljic K, Magic Z (2018) Epigenetic nutraceuticals in cancer treatment. in: Holban AM, Grumezescu AM (eds.) Therapeutic Foods. Academic Press 8 . 449-494.

16. Esteller M (2018) The Human Epigenome_Implications for the Understanding of Human Disease. In: Coleman WB and Tsonsalis GJ (eds.) Molecula Pathology (Second Edition). Academic Press. 165-182.

17. Munir MT, Ponce C, Powell CA, Tarafdar K, Yanagita T (2018) The contribution of cholesterol and epigenetic changes to the pathophysiology of breast cancer J Steroid Biochem Mol Biol 183: 1-9.

18. Porcellini E, Laprovitera N, Riefolo M, Ravaioli M, Garajova I, et al. (2018) Epigenetic and epitranscriptomic changes in colorectal cancer: Diagnostic prognostic, and treatment implications. Cancer Lett 419: 84-95.

19. Barrow TM (2018) Epigenetic epidemiology for cancer risk. in: Epigenetic Mechanisms in Cancer. Boston: Academic Press.

20. Clifford RL, Jones MJ, Maclsaac JL, McEwen LM, Goodman SJ, et al. (2017) Inhalation of diesel exhaust and allergen alters human bronchial epithelium DNA methylation. J Allergy Clin Immunol 139: 112-121.

21. Higgins SP, Tang Y, Higgins CE, Mian B, Zhang W (2018) TGF-beta1/p53 signaling in renal fibrogenesis. Cell Signal 43: 1-10.

22. Zeng Y, Shen Z, Gu W, Wu M (2018) Inhibition of hepatocellular carcinoma tumorigenesis by curcumin may be associated with CDKN1A and CTGF. Gene 651: 183-193.

23. Dai M, Al-Odaini AA, Arakelian A, Rabbani SA, Ali S, et al (2012) A nove function for $\mathrm{p} 21 \mathrm{Cip} 1$ and acetyltransferase $\mathrm{p} / \mathrm{CAF}$ as critical transcriptional regulators of TGFbeta-mediated breast cancer cell migration and invasion. Breast Cancer Res 14: R127.

24. Zhang P, Zhao G, Ji L, Yin J, Lu L (2018) Knockdown of survivin results in inhibition of epithelial to mesenchymal transition in retinal pigment epithelial cells by attenuating the TGFbeta pathway. Biochem Biophys Res Commun 498: 573-578.

25. Fang $P$, Xue $Y$, Zhang $Y$, Fan $N$, Ou L, et al. (2018) SIRT7 regulates the TGF- $\beta 1$-induced proliferation and migration of mouse airway smooth muscle cells by modulating the expression of TGF- $\beta$ receptor I. Biomedicine \& Pharmacotherapy 104: 781-787.

26. de Araujo Farias V, Carrillo-Gálvez AB, Martín F, Anderson P (2018). TGF- $\beta$ and mesenchymal stromal cells in regenerative medicine, autoimmunity and cancer. Cytokine Growth Factor Rev 43: 25-37.

27. Rodgers KM, Udesky JO, Rudel RA, Brody JG (2018) Environmental chemicals and breast cancer: An updated review of epidemiological literature informed by biological mechanisms. Environ Res 160: 152-182.

28. Reis H, Reis C, Sharip A, Reis W, Zhao YS, et al. (2018) Diesel exhaust exposure, its multi-system effects, and the effect of new technology diesel exhaust. Environ Int 114: 252-265.

29. Bowe B, Xie Y, Li T, Yan Y, Xian H , et al. (2018) The 2016 global and national burden of diabetes mellitus attributable to PM2.5 air pollution. The Lance Planetary Health 2: e301-e312.

30. Olvera Alvarez HA, Kubzansky LD, Campen MJ, Slavich GM (2018). Early life stress, air pollution, inflammation, and disease: An integrative review and immunologic model of social-environmental adversity and lifespan health Neurosci Biobehav Rev 92: 226-242.

31. Thiering E, Heinrich J (2015) Epidemiology of air pollution and diabetes. Trends in Endocrinology \& Metabolism 26: 384-394

32. Niemann B, Rohrbach S, Miller MR, Newby DE, Fuster V, et al. (2017) Oxidative stress and cardiovascular risk: Obesity, diabetes, smoking, and pollution: Part 3 of a 3-part series. J Am Coll Cardiol 70: 230-251.

33. Hinck AP (2018) Structure-guided engineering of TGF- $\beta$ s for the development of novel inhibitors and probing mechanism. Bioorganic \& Medicinal Chemistry 26: 5239- 5246.

34. Maldonado L, Brait M, Izumchenko E, Begum S, Chatterjee A, et al. (2018). Integrated transcriptomic and epigenomic analysis of ovarian cancer reveals epigenetically silenced GULP1. Cancer Lett 433: 242.

35. Fougere B, Landkocz Y, Lepers C, Martin PJ, Armand L (2018) Influence of aging in the modulation of epigenetic biomarkers of carcinogenesis after exposure to air pollution. Exp Gerontol 110: 125-132.

36. Callahan CL, Bonner MR, Nie J, Han D, Wang Y, et al. (2018). Lifetime exposure to ambient air pollution and methylation of tumor suppressor genes in breas tumors. Environ Res 161: 418-424. 
Citation: Shaat R, Abdel-Ghany SE, Nasr GM, Sabit H, El-Zawahry M (2019) Modulation of Epigenetic Profiles in Traffic Workers Exposed to Car Fumes in Egypt. Mol Biol 8: 225. doi: 10.4172/2168-9547.1000225

Page 7 of 7

37. Billet S, Landkocz Y, Martin PJ, Verdin A, ledoux F, et al. (2018) Chemical characterization of fine and ultrafine PM, direct and indirect genotoxicity of PM and their organic extracts on pulmonary cells. J Environ Sci.

38. Ros XR, Vermeulen L (2018) Turning Cold Tumors Hot by Blocking TGF- $\beta$. Trends in Cancer 4: 335-337.

39. Apparicio P, Gelb J, Carrier M, Mathieu ME, Kingham S (2018) Exposure to noise and air pollution by mode of transportation during rush hours in Montreal. J Transp Geog 70: 182-192.
40. Mccullough SD, Dhingra R, Fortin MC, Diaz-Sanchez D (2017)Air pollution and the epigenome: A model relationship for the exploration of toxicoepigenetics. Curr Opin Toxicol 6: 18-25.

41. Clifford RL, Jones MJ, Maclsaac JL, McEwen LM, Goodman SJ, et al. (2017) Inhalation of diesel exhaust and allergen alters human bronchial epithelium DNA methylation. J Allergy Clin Immunol 139: 112-121.

42. Ding R, Jin Y, Liu X, Zhu Z, Zhang Y, et al. (2016) Characteristics of DNA methylation changes induced by traffic-related air pollution. Mutation Research/ Genetic Toxicology and Environmental Mutagenesis 796: 46-53. 